Gut, 1973, 14, 59-63

\title{
Treatment of bleeding oesophageal varices by infusion of vasopressin into the superior mesenteric artery
}

\author{
IAIN M. MURRAY-LYON, R. N. H. PUGH, H. B. NUNNERLEY, J. W. LAWS, \\ J. L. DAWSON, AND ROGER WILLIAMS \\ From the Liver Unit and Department of Radiology, King's College Hospital and Medical School, \\ London
}

SUMMARY Seventeen patients bleeding from oesophageal varices were treated by continuous infusion of vasopressin through a catheter inserted percutaneously and positioned in the superior mesenteric artery and in two other patients catheterization proved technically impossible. Bleeding was completely controlled on only four out of 18 occasions in the 17 patients treated. In seven patients, bleeding was controlled for two or more days but then recurred although the infusion was continued with an increased dose of vasopressin. There was a high incidence of complications, including bleeding from the site of catheter insertion in the groin and septicaemias. Sengstaken balloon tamponade and oesophageal transection had to be used to control bleeding in some patients but only six out of 17 survived to leave hospital.

The treatment of bleeding oesophageal varices represents a continuing challenge as the mortality during the first hospital admission has remained at around $50 \%$ for the past 30 years (Ratnoff and Patek, 1942; Nachlas, O'Neil, and Campbell, 1955; Hislop, Waters, Kellock, and Swynnerton, 1966). Unless haemorrhage can be quickly controlled, the consequent fall in liver blood flow leads to deteriorating liver function and coagulation tests, making the bleeding even more difficult to control. Various forms of balloon tamponade (Bertrand and Michel, 1969; Pitcher, 1971) are effective in the short term but aspiration pneumonia and other serious complications are common, and haemorrhage subsequently recurs in many patients. Likewise, systemic vasopressin is usually only temporarily effective (Shaldon and Sherlock, 1960) and its use is limited by coronary artery constriction leading sometimes to myocardial infarction or serious arrythmia (Beller, Trevino, and Urban, 1971).

In 1967, Nusbaum, Baum, Sakiyalek, and Blakemore showed in dogs that the infusion of a small dose of vasopressin into the superior mesenteric artery reduced arterial flow and portal venous pressure without altering systemic arterial pressure or cardiac output and with no evidence of bowel Received for publication 7 November 1972. ischaemia during infusions lasting for up to six hours. Subsequently these workers and others in America used this technique in man for the rapid control of variceal haemorrhage with encouraging results (Nusbaum, Baum, Kuroda, and Blakemore, 1968; Nusbaum, Baum, and Blakemore, 1969; Baum and Nusbaum, 1971; Rösch, Dotter, and Rose, 1971; Stahl, 1971; Conn, Ramsby, and Storer, 1972). Our experience has been somewhat different and in this paper we describe the results obtained in the treatment of 19 patients admitted as an emergency with massive bleeding from oesophageal varices.

\section{Patients and Methods}

Eighteen patients had cirrhosis (10 alcoholic, four cryptogenic, two primary biliary, and two active chronic hepatitis), the remaining patient having an extrahepatic portal vein block. The majority of the cirrhotic patients had evidence of liver failure, with ascites in 14 and encephalopathy in 13. The serum bilirubin at the time of admission was more than $2 \mathrm{mg} / 100 \mathrm{ml}$ in 12 patients and the prothrombin time was prolonged by more than three seconds in 12 patients (Table I). Oesophageal varices were demonstrated in each patient either on barium meal 


\begin{tabular}{|c|c|c|c|c|c|c|c|c|c|c|}
\hline \multirow[t]{2}{*}{ Case } & \multirow[t]{2}{*}{ Age } & \multirow[t]{2}{*}{$\operatorname{sex}$} & \multirow[t]{2}{*}{ Aetiology } & \multicolumn{2}{|l|}{ Serum } & \multirow{2}{*}{$\begin{array}{l}\text { Prothrombin } \\
\text {-Time (sec } \\
\text { prolonged) }\end{array}$} & \multirow{2}{*}{$\begin{array}{l}\text { Duration of } \\
\text { Vasopressin } \\
\text { Infusion } \\
\text { (days) }\end{array}$} & \multirow{2}{*}{$\begin{array}{l}\text { Sengstaken } \\
\text { Tube } \\
\text { (day) }\end{array}$} & \multirow{2}{*}{$\begin{array}{l}\text { Control of } \\
\text { Bleeding } \\
\text { (days) }\end{array}$} & \multirow{2}{*}{$\begin{array}{l}\text { Complications and Clinical } \\
\text { Outcome }\end{array}$} \\
\hline & & & & $\begin{array}{l}\text { Bilirubin } \\
(\mathrm{mg} / \\
100 \mathrm{ml})\end{array}$ & $\begin{array}{l}\text { Albumin } \\
(\mathrm{g} / \\
100 \mathrm{ml})\end{array}$ & & & & & \\
\hline $\begin{array}{l}1 \\
2\end{array}$ & $\begin{array}{l}55 \\
56\end{array}$ & $\begin{array}{l}\mathbf{M} \\
\mathbf{M}\end{array}$ & $\begin{array}{l}\text { Alcoholic } \\
\text { Alcoholic }\end{array}$ & $\begin{array}{l}3 \cdot 7 \\
3 \cdot 5\end{array}$ & $\begin{array}{l}2 \cdot 6 \\
2 \cdot 8\end{array}$ & $\begin{array}{l}\mathbf{0} \\
8\end{array}$ & $\begin{array}{l}11 \\
12\end{array}$ & $\begin{array}{l}\mathbf{0} \\
\mathbf{0}\end{array}$ & $\begin{array}{l}\text { Complete } \\
\text { Complete }\end{array}$ & $\begin{array}{l}\text { Died } 2 \text { months bleeding } \\
\text { Died } 6 \text { months hepatic } \\
\text { failure }\end{array}$ \\
\hline $\begin{array}{l}3 \\
4\end{array}$ & $\begin{array}{l}58 \\
40\end{array}$ & $\begin{array}{l}\mathbf{M} \\
\mathbf{M}\end{array}$ & $\begin{array}{l}\text { Alcoholic } \\
\text { Alcoholic }\end{array}$ & $\begin{array}{l}35 \cdot 5 \\
50 \cdot 5\end{array}$ & $\begin{array}{l}2 \cdot 9 \\
2 \cdot 6\end{array}$ & $\begin{array}{l}5 \\
4\end{array}$ & $\begin{array}{l}7 \\
9\end{array}$ & $\begin{array}{r}0 \\
11\end{array}$ & $\begin{array}{l}0-4 \\
0-5\end{array}$ & $\begin{array}{l}\text { Died day } 7 \text { bleeding } \\
\text { Transection of oesophagus } \\
\text { day } 11 \text {; cardiac arrest } \\
\text { day } 20\end{array}$ \\
\hline $\begin{array}{l}5 \text { (1st } \\
\text { admission) } \\
5 \text { (2nd } \\
\text { admission) }\end{array}$ & 50 & $\mathbf{M}$ & Cryptogenic & 1.5 & $2 \cdot 5$ & 4 & 9 & $7-8$ & Nil & $\begin{array}{l}\text { Transection of oesophagus } \\
\text { day } 9 \text {; discharged } \\
\text { Died day } 5 \text { bleeding }\end{array}$ \\
\hline $\begin{array}{l}6 \\
7\end{array}$ & $\begin{array}{l}50 \\
25\end{array}$ & $\begin{array}{l}\mathbf{M} \\
\mathbf{M}\end{array}$ & $\begin{array}{l}\text { Cryptogenic } \\
\text { Extra- } \\
\text { hepatic } \\
\text { portal vein } \\
\text { block }\end{array}$ & $\begin{array}{l}5 \cdot 1 \\
1 \cdot 5\end{array}$ & $\begin{array}{l}3 \cdot 6 \\
3 \cdot 2\end{array}$ & $\begin{array}{l}5 \\
1\end{array}$ & $\begin{array}{r}24 \\
2\end{array}$ & $\underset{2}{1-2} \& 24$ & $\begin{array}{l}0-4 \\
\mathrm{Nil}\end{array}$ & $\begin{array}{l}\text { Died day } 35 \text { bleeding } \\
\text { Transection of oesophagus } \\
\text { day } 2 \text {; discharged }\end{array}$ \\
\hline $\begin{array}{l}8 \\
9\end{array}$ & $\begin{array}{l}51 \\
48\end{array}$ & $\begin{array}{l}\mathbf{M} \\
\mathbf{F}\end{array}$ & $\begin{array}{l}\text { Alcoholic } \\
\text { Primary } \\
\text { biliary }\end{array}$ & 18 & $\begin{array}{l}3 \cdot 1 \\
1 \cdot 8\end{array}$ & $\begin{array}{r}5 \\
10\end{array}$ & $\begin{array}{r}10 \\
7\end{array}$ & $\begin{array}{l}8 \\
5\end{array}$ & $\begin{array}{l}0-7 \\
0-2\end{array}$ & $\begin{array}{l}\text { Died day } 10 \text { bleeding } \\
\text { Died day } 7 \text { bleeding }\end{array}$ \\
\hline $\begin{array}{l}10 \\
11 \\
12 \\
13\end{array}$ & $\begin{array}{l}48 \\
62 \\
60 \\
63\end{array}$ & $\begin{array}{l}\mathbf{M} \\
\mathbf{F} \\
\mathbf{M} \\
\mathbf{M}\end{array}$ & $\begin{array}{l}\text { Cryptogenic } \\
\text { Alcoholic } \\
\text { Alcoholic } \\
\text { Active } \\
\text { chronic }\end{array}$ & $\begin{array}{l}21 \cdot 5 \\
19 \\
2 \cdot 0 \\
13\end{array}$ & $\begin{array}{l}2 \cdot 1 \\
2 \cdot 9 \\
2 \cdot 0 \\
-\end{array}$ & $\begin{array}{r}8 \\
8 \\
3 \\
-\end{array}$ & $\begin{array}{r}11 \\
8 \\
6 \\
1\end{array}$ & $\begin{array}{l}1-2 \\
4 \& 6 \\
1 \\
1\end{array}$ & $\begin{array}{l}\text { Nil } \\
\text { Nil } \\
0-4 \\
\text { Complete }\end{array}$ & $\begin{array}{l}\text { Died day } 11 \text { bleeding } \\
\text { Died day } 8 \text { bleeding } \\
\text { Died day } 10 \text { lives failure } \\
\text { Died day } 2 \text { ruptured } \\
\text { valve cusp }\end{array}$ \\
\hline 14 & 58 & $\mathbf{F}$ & $\begin{array}{l}\text { Primary } \\
\text { biliary }\end{array}$ & $2 \cdot 3$ & $3 \cdot 5$ & 2 & 1 & 1 & Complete & $\begin{array}{l}\text { Mesenteric-caval shunt } \\
\text { day 2; discharged }\end{array}$ \\
\hline 15 & 50 & $\mathbf{F}$ & Alcoholic & 27 & $2 \cdot 8$ & 8 & 5 & $\mathbf{0}$ & Nil & $\begin{array}{l}\text { Transection of oesophagus } \\
\text { day 5; discharged }\end{array}$ \\
\hline 16 & 57 & $\mathbf{M}$ & $\begin{array}{l}\text { Active } \\
\text { chronic }\end{array}$ & - & - & - & 2 & 1 & Nil & Died day 2 bleeding \\
\hline 17 & 38 & $\mathbf{F}$ & Alcoholic & 1.5 & $2 \cdot 8$ & 6 & 1 & 1 & Nil & $\begin{array}{l}\text { Transection of oesophagus } \\
\text { day 4; died day } 6 \\
\text { meningitis }\end{array}$ \\
\hline
\end{tabular}

Table Relevant clinical data in the 17 patients who had a superior mesenteric artery infusion of vasopressin

or at oesophagoscopy and no other source for the bleeding was found.

Using the Seldinger technique under local anaesthesia, a reverse curved red Kifa catheter with a single hole was inserted into the femoral artery and manipulated into the superior mesenteric artery. Twenty $\mathrm{ml}$ Conray 420 was then injected at 10 $\mathrm{ml} /$ second and serial films were taken at one film/ second starting after the first $10 \mathrm{ml}$ of contrast medium had been injected. Aqueous vasopressin was then infused at $\mathbf{0 . 2}$ units/minute for 10 minutes and after flushing the catheter with saline a further series of films was taken. In some of the later patients, the timed films were omitted and only a single film was taken to confirm the position of the catheter which was then fixed to the skin of the groin by sutures. Subsequently in the ward, films were taken at regular intervals to check that the catheter remained in position.

An Ivac 501 continuous infusion pump (Tekmar Medical Limited, Harrow) was used to give the vasopressin which was contained in $5 \%$ dextrose in closed polythene bags (Steriflex) to obviate the risk of air embolism. Initially 0.2 units $/ \mathrm{ml} / \mathrm{min}$ were given but if bleeding continued the dose was doubled or trebled and on one occasion increased to 0.8 units/minute.

\section{Results}

In one patient it was not possible to catheterize the superior mesenteric artery because of extreme tortuosity of the vessels and in another the hepatic artery arose from the superior mesenteric artery making selective infusion impossible. The remaining 17 patients received 18 trials of treatment (Table) as case 5, who was discharged home after the first, had a further bleed requiring treatment some months later. On 10 occasions the patients were treated by superior mesenteric artery infusion alone (Fig. 1), but bleeding was completely controlled in only two of these (cases 1 and 2). In four patients (cases 3, 4, 8, and 9) bleeding stopped for two or more days but then recurred even though the infusion was being continued. In each case the catheter was correctly positioned, and increasing the dose of vasopressin had no effect. In four patients (cases 5 , first admission, $7,11,15$ ) the initial bleeding was 


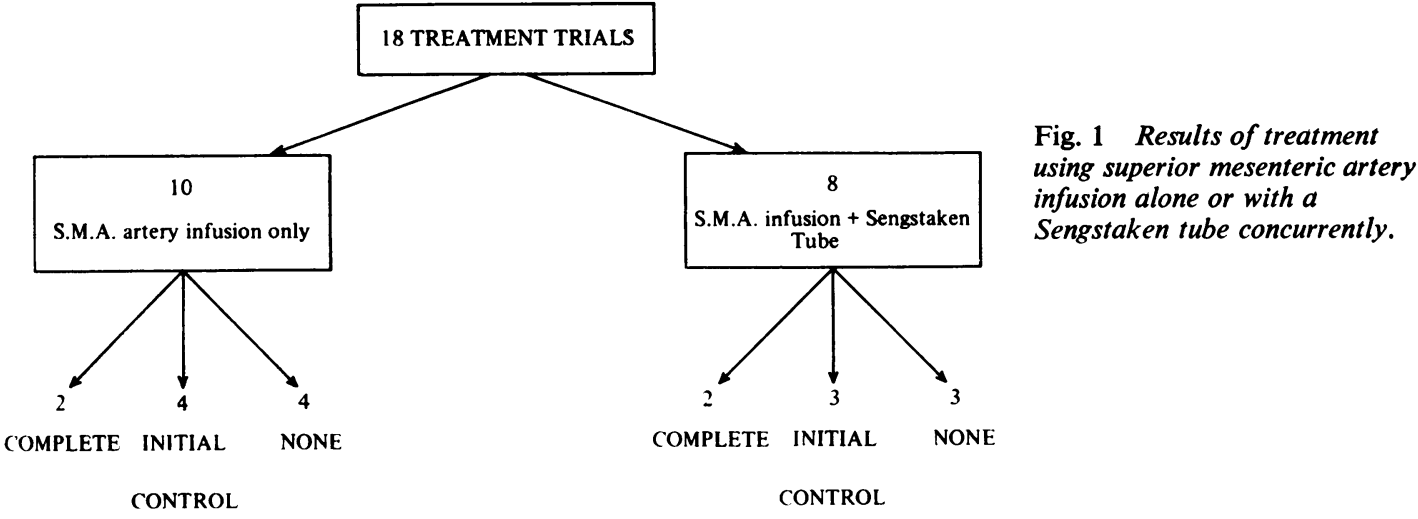

never satisfactorily controlled. One of these in whom there was arteriographic evidence of superior mesenteric artery vasoconstriction when the infusion was started (Fig. 2), required a Sengstaken tube and then a transection of the oesophagus to stop the haemorrhage (Fig. 3). Indeed, no correlation could be observed between vasoconstriction demonstrated on the arteriogram at the beginning of the infusion, and subsequent control of the bleeding.

Because of the failure to control the bleeding consistently, it was decided to use a Sengstaken tube for the first one to two days in conjunction with superior mesenteric artery infusion. This was done on eight occasions but without improvement in the results. Bleeding was completely controlled in two patients (cases 13,14) but one of them died on the second day with a ruptured aortic valve cusp due to acute bacterial endocarditis. In three patients (cases 5 , second admission, 6,12 ) bleeding was controlled initially but recurred some time after the balloons were deflated although the infusion was continued.

\section{COMPLICATIONS}

Six patients developed either a large haematoma in the groin or persistent arterial bleeding and in three of these the artery had to be repaired surgically. The infusion catheter became occluded by thrombus

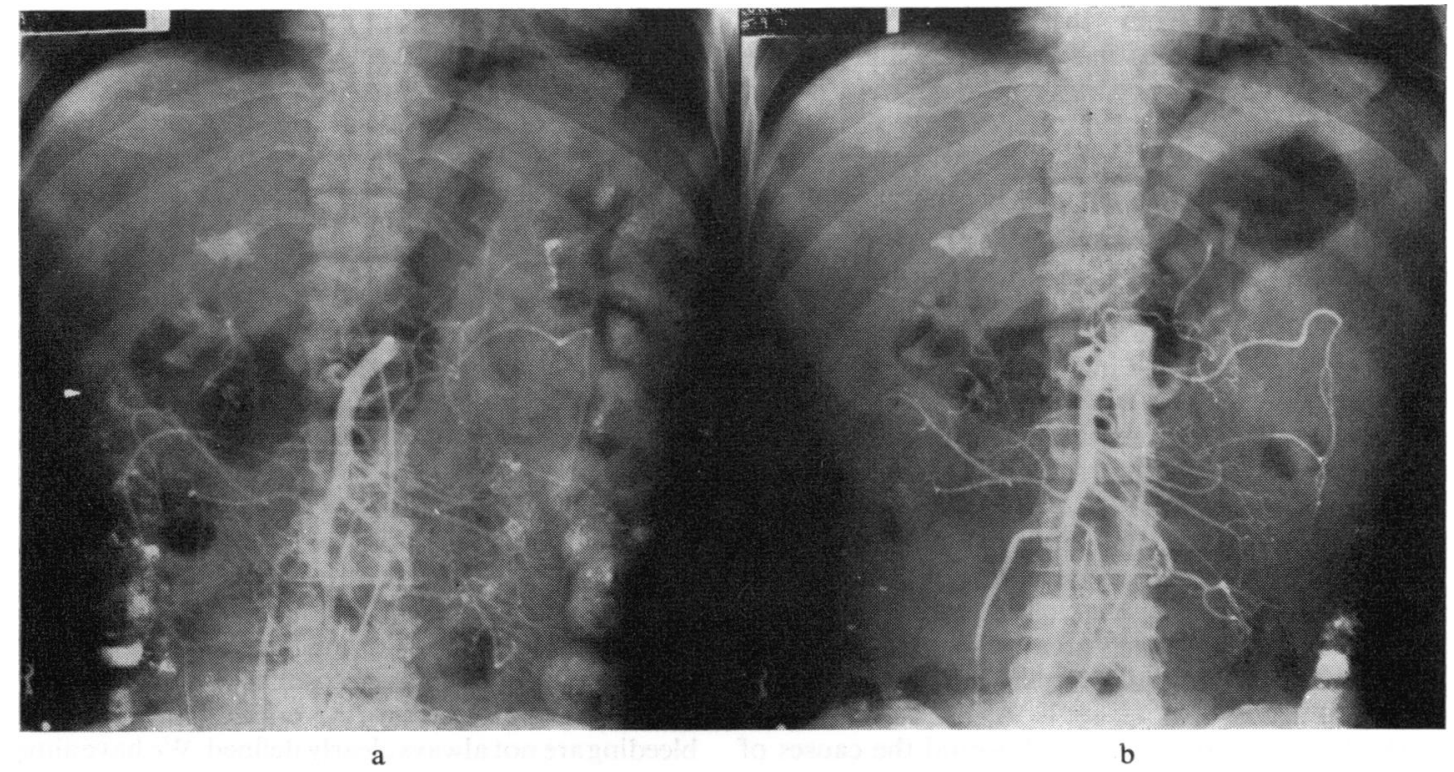

Fig. 2 Superior mesenteric arteriograms in case 5 (first admission) before (a) and following (b) 10 min infusion with vasopressin 0.2 units/min. Note the constriction of the superior mesenteric artery and its branches and reflux of contrast into the aorta. 


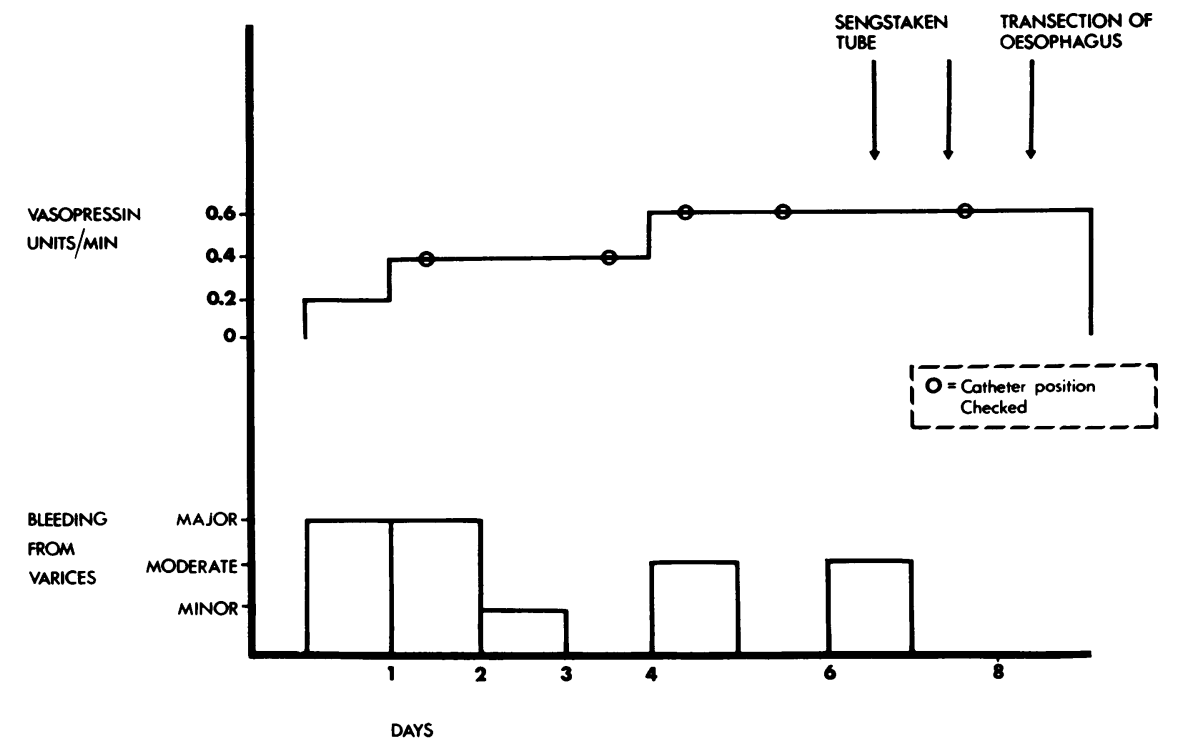

Fig. 3 The clinical course in case 5 (first admission) showing the increasing dose of vasopressin infused, recurrence of bleeding, and the use of other procedures.

on two occasions and in two other patients nonocclusive thrombus was found at necropsy in the aorta or femoral artery in proximity to the catheter. In one patient severe femoral artery spasm necessitated removal of the catheter. The catheter became dislodged from the superior mesenteric artery on six occasions in five patients and because of the risk of infection with repositioning a new catheter was inserted in the opposite groin. Nevertheless, in the complete series three patients developed pyrexia and leucocytosis, and in one $E$. coli was subsequently grown from the catheter tip.

SURVIVAL AND OVERALL RESULTS

Only six (35\%) of the 17 patients treated survived to leave hospital, these including three of the five patients (see Table), who because of continuing bleeding underwent transthoracic transection of the oesophagus and ligation of varices, and another who had a mesenteric-caval shunt performed. She remains well at three months, and two (cases 7 and 15) of those who had interruption of varices have not bled again after nine and two months respectively. The other three patients died within six months from further haemorrhage or hepatic failure.

Of the 12 patients dying in hospital the causes of death were haemorrhage (8), hepatic failure (1), bacterial endocarditis (1), pneumococcal meningitis (1), and unexplained cardiac arrest (1).

\section{Discussion}

In this series we achieved complete control of variceal haemorrhage by vasopressin infusion on only four out of 18 occasions and the two patients in whom catheterization of the superior mesenteric artery was not technically possible must also be considered as failures of treatment. This is to be contrasted with the results reported by Baum and Nusbaum (1971) with control of bleeding in 27 of 28 patients. These workers never found it necessary to use more than 0.4 units of vasopressin per minute, and, whenever arteriographic films showed arterial narrowing or delay in clearing the dye from the mesenteric circulation, they found a significant drop in the portal venous pressure as measured by catheterization of the umbilical vein or by hepatic venous wedge pressure. Rösch et al (1971) reported control of acute bleeding in all five patients treated for up to four hours and Stahl (1971) had been able to control haemorrhage in each of the 24 cirrhotic patients so treated. However, none of these series is reported in sufficient detail to make comparison with our patients possible, and it is noteworthy that the period of infusion in many cases was limited to only a few hours. Furthermore the criteria for control of bleeding are not always clearly defined. We haveaimed to control variceal haemorrhage for at least a week in order to allow time for improvement in the patient's general condition and liver function, so 
that oesophageal transection or portal systemic shunting in selected cases may then be undertaken under more favourable conditions. Although verification by oesophagoscopy that the varices were the site of bleeding was not obtained in every patient, no other source of haemorrhage was discovered in those coming to necropsy, and in others bleeding stopped promptly following transection of the oesophagus or a shunt procedure. In the seven patients in whom bleeding was controlled initially but recurred subsequently despite continuation of the infusion, resistance to vasopressin (tachyphlaxis) may have developed. Aqueous vasopressin contains an unknown and variable mixture of beef and pork pituitary hormone and it is of course possible that the preparations available in different countries vary.

The only serious complication mentioned in the early series was femoral artery spasm in one case which required removal of the catheter (Rösch et al, 1971), although more recently Conn et al (1972) in reporting control of bleeding for at least 24 hours in 10 of 11 patients did observe infected ascites, bacteraemia, intestinal necrosis, and cardiac arrythmias, and Renert, Button, Fuld, and Casarella (1972) described the development of mesenteric venous thrombosis and small intestinal infarction. The complications in our patients were both numerous and serious. The high incidence of local bleeding in the groin was almost certainly related to the marked prolongation of the prothrombin time present in so many of them. Cirrhotic patients are particularly prone to develop septicaemias (Tisdale, 1961) and the presence of an indwelling arterial catheter must further increase this risk. Indeed with this high complication rate and poor overall results we do not feel justified in continuing to use vasopressin infusion in this way.

We are grateful to Drs M. O. Rake, C. O. Record,
A. R. Davidson, and our house physicians for help with the care of these patients.

The support of the Medical Research Council is also gratefully acknowledged.

\section{References}

Baum, S., and Nusbaum, M. (1971). The control of gastrointestinal hemorrhage by selective mesenteric arterial infusion of vasopressin. Radiology, 98, 497-505.

Beller, B. M., Trevino, A., and Urban, E. (1971). Pitressin-induced myocardial injury and depression in a young woman. Amer. J. Med., 51, 675-679.

Bertrand, L., and Michel, H. (1969). La sonde de Linton-Nachlas: sa supériorité sur celle de Sengstaken-Blakemore pour le tamponnement des varices oeso-gastriques chez le cirrhotique. Arch. Mal. Appar. dig., 58, 797-816.

Conn, H. O., Ramsby, G. R., and Storer, E. H. (1972). Intra-arterial vasopressin in the treatment of upper gastrointestinal hemorrhage. Gastroenterology, 62,868 .

Hislop, I. G., Waters, T. E., Kellock, T. D., and Swynnerton, B. (1966). The natural history of haemorrhage from oesophageal varices. Lancet, 1, 945-948.

Nachlas, M. M., O’Neil, J. E., and Campbell, A. J. A. (1955). The life history of patients with cirrhosis of the liver and bleeding esophageal varices. Ann. Surg., 141, 10-23.

Nusbaum, M., Baum, S., and Blakemore, W. S. (1969). Clinical experience with the diagnosis and management of gastrointestinal hemorrhage by selective mesenteric catleterization. Ann. Surg., 170, 506-514.

Nusbaum, M., Baum, S., Kuroda, K., and Blakemore, W. S. (1968) Control of portal hypertension by selective mesenteric arterial drug infusion. Arch. Surg., 97, 1005-1013.

Nusbaum, M. Baum, S., Sakiyalek, P., and Blakemore, W. S. (1967) Pharmacologic control of portal hypertension. Surgery, 62, 299-310.

Pitcher, J. L. (1971). Safety and effectiveness of the modified Sengstaken-Blakemore tube: a prospective study. Gastroenterology, 61, 291-298.

Ratnoff, O. D., and Patek, A. J., Jr. (1942). The natural history of Laennec's cirrhosis of the liver. An analysis of 386 cases. Medicine (Baltimore), 21, 207-268.

Renert, W. A., Button, K. F., Fuld, S. L., and Casarella, W. J. (1972) Mesenteric venous thrombosis and small-bowel infarction following infusion of vasopressin into the superior mesenteric artery. Radiology, 102, 299-302.

Rösch, J., Dotter, C. T., and Rose, R. W. (1971). Selective arterial infusions of vasoconstrictors in acute gastro-intestinal bleeding. Radiology, 99, 27-36.

Shaldon, S., and Sherlock, S. (1960). The use of vasopressin (Pitressin) in the control of bleeding from oesophageal varices. Lancet, 2, 222-225.

Stahl, W. M. (1971). In discussion. Amer. J. Surg., 121, 117.

Tisdale, W. A. (1961). Spontaneous colon bacillus bacteremia in Laennec's cirrhosis. Gastroenterology, 40, 141-148. 